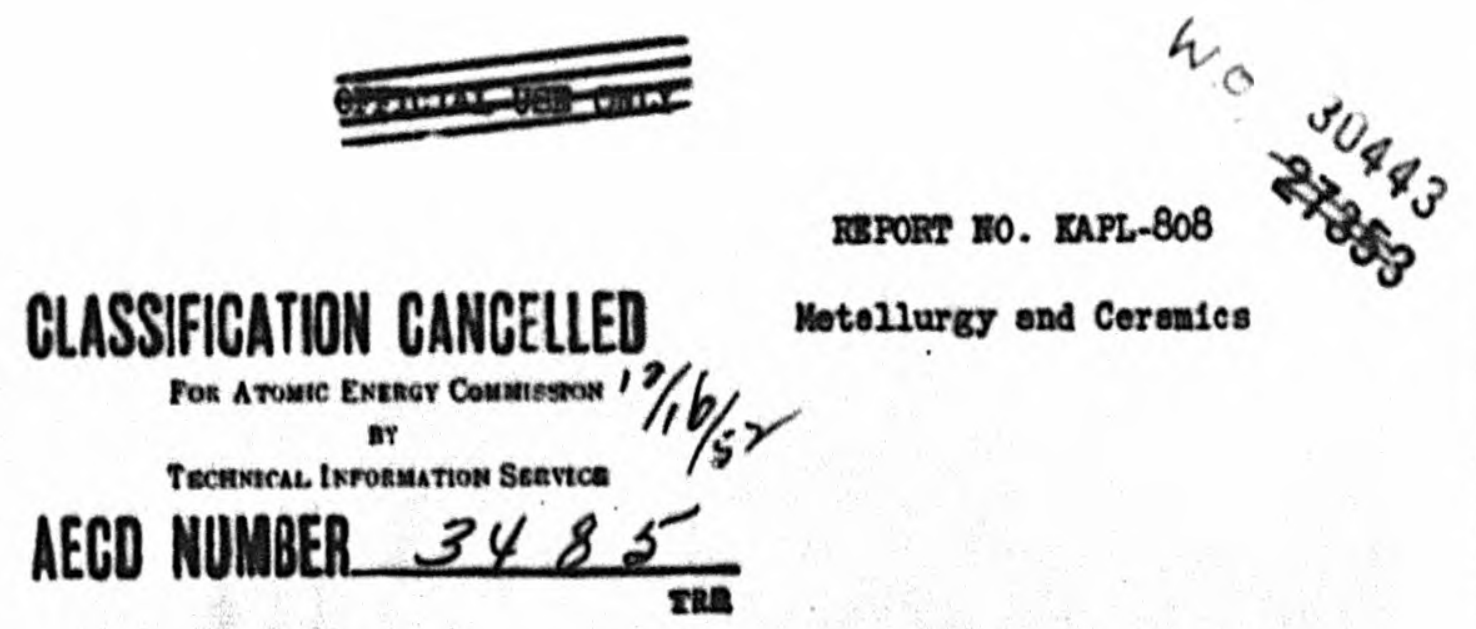

\author{
General Blectric Colapeny \\ ETOUS ATONIC POVIBB IABORATORY \\ Schenectody, Ilow Jork
}

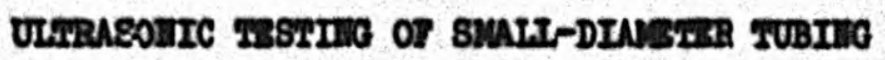

A. J. Perdus

Pebruery 1, 1952

\author{
Operated for the \\ Onited Stetes Atonfo Inereg Comission \\ by the \\ Cenerel Eloetric Compeny \\ Contrect Ilo. W-31-109 Eng-52
}




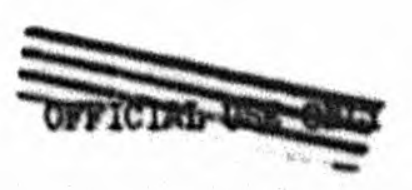

\section{LISP of InwSTrartons}

Pege

Figure 1 Testing Setup . . . . . . . . . . . . . 23

Figure 2 Holder and Gear Arrongement . . . . . . . . . 23

Tigure 3 Mejor Components of 1-Inch Angle Searching Unit . . . 25

Pigure 4 Angle Seerching Unit Assembly . . . . . . . . . 25

Tigure 5 Initiel Pulse - Wo Defects - Beck Beflection . . . . 27

Figure 6 File Notch Defect, $40^{\circ}$ Circumferent10l, 0.005 Inch

Deeg . . . . . . . . . . . . . . . 27

P1gure 7 llotch Defect, $180^{\circ}$ C1rcumferent101, 0.002 Inch Deep,

2 Inches from Ind of Tube . . . . . . . . . . 29

I1gure 8 Jlotch Defect, $180^{\circ}$ C1reumferent1el, 0.002 Inch Deep,

3 Inches from snd of Tube .. . . . . . . . . 29

F1gure 9 Double Notch Defoct, 0.002 Inch ond 0.001 Ineh Deep,

3 Inches and 4 Inches, Respectively, from End of Tube . 31

F1gure 10 Iotch Defect, $45^{\circ}$ C1rcumferent1al, 0.001 Inch Doep, Angle Searching Onit 7 Inches from End of Tube . . . . . 31

Figure 11 Axlal Groove Defect, 1/4 Inch Iong, 1/32 Inch W1de, 0.005 Inch Deep, 2 Inches from End of Tube . . . . 33

F1gure 12 Same Ilotch Defect as Shown in F1g. 10, Increesed Sensitivity, Angle Seerching Onit 16 Inches from End of Tube ................. 33

Figure 13 Hole Defoct in 0.010-Inch Well, 0.0135 Inch Diemeter,

4 Inches from Ind of Tube . . . . . . . . . 35

Figure 14 Same Defect as Shown in F1g. 13, Inoressed Sensitivity - 35

Figure 15 Axilal Groove Dofect, $1 / 4$ Inch Iong, 0.006 Inch Vide, 0.005 Inch Deep, 4 Inches from snd of Tubing . . . . 37

F1gure 16 Same Defect as Shown in Fig. 15, Inereased Bonsitivity - 37

Figure 17 Solid Steel Bod, 0.080 Inch Dla., Io Defect, Shown are First and Second Back End Beflections . . . . . 39 


\section{Acriourspeivin}

The informotion presented in this report hes been essenbled ond orgen1zed in the Ilondestructive Test Section in the Schenectedy Horks.

The outhor vishes to express h1s oppreciotion for the personol interest and encouregement of $\mathrm{Mr}$. T. J. Cesheen, Supervisor of the reeting section of the Besetor Components Sub-Unst ot KaPL.

Be vould also 11 ke to thenk Wr. C. D. Morlerty, Ne. M. Demm1s, Mr. H. Boche, Mr. H. B. Conley, and Vr. B. G. Wallingford for thoir helpful eesletance and suggestions during this developwent.

Thenks are extended to Ifr. Ted steck who mede the photographs.

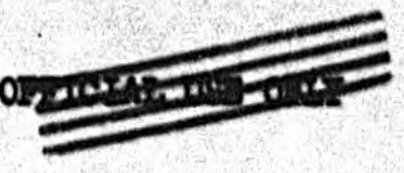




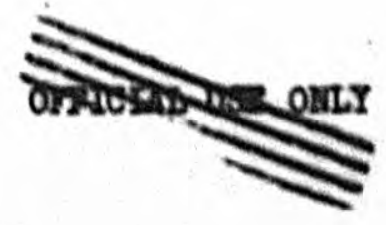

With the development of the procedure and equipment outlined in th1s report, ultrosonics can be applied successfully to locote flows in 0.060 in. ID $\times 0.080$ in. OD tubing. By meens of high-frequency pulsating sound woves sent into the tubing to be tosted, flews ore loceted by reflection of the sound vaves from the defect. Any discontinuity, os vell os the opposite end of the tubing, vill reflect the veve beck to the searching unit which presents it on the reflectoscope. In the testing of thin-velled tubing, o sheer veve is genereted by on ongle quarts crystel, and is sent ongulorly into the tubing being testod. Best results vore obtained with a l-megecyelo, 1-1n. quertz-erystel, onglo-seorching unit. H1gher frequeney cryetels, $21 / 4$ megecycles ond 5 megecycles, vere 0180 tried but vere unsuccessfol due to high ottenuetion of the sonic onergs.

Prior to the development of this procedure, no sat1sfectory moens of detecting and meesuring defects in smoll-dismeter, thin-wolled tubing hed been ava1lable.

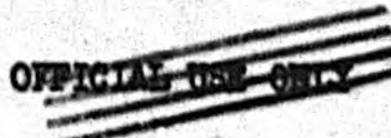


ULARASONIC TESTIMG OF SMALL-DIALETER TUBIMO

The llondestructive Test Oroup in the Generel Electr1e Works Leborotory aede a ohort Investigation of ultresonic testing of smell-diemeter tubing; the results showed that ultresonic testing might be feasible when the shear vevo is perallel to the longitudinel axis. Hovever, considerable doubt remoined os to the size of the defect that could be detected.

Lerge s1ze pipes, of alemeters greater then $11 / 2$ in., heve been successfully tested by using shoer voves generated perpendiculer to the long1tudinal ex18. Hovever, ultresonic testing by th1s method of p1pe or tubing smeller then $11 / 2$ in. OD vould be highly 1 mpracticeble due to the per1od of blenking of the receiver at the instent of the pulse trensmission. Unfortunately, this receiver blenking lests for opprorimetely 150 mleroseconds and couplotely cencels ony reflection fros the first $11 / 2$ in. of moteriol.

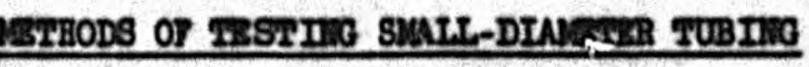

Since all present nothods of testing small-diometer tubing hove lim1tetions, and because of the 1mportance of detecting defects in smoil-diemeter tubing, the ultresonie method wes developed and two other methods are now being studied. The ultresonic method vill be compared with these two methods, and oll vill be correleted vith hydrostatic pressure tests if possible.

\section{Leak Testing}

By the use of a mass -spectrometer-type leak detector, small leaks in tubing have been found vith leak rates as low as $1 \times 10^{-8}$ std ce/second. This test is not effective unless the defect extends through the entire vell of the tubing.

\section{Bubble Testing}

Large leaks cen bo detected by the streams of bubbles esceping from vithin the tubing. This test is olso not effective unless the defect extends through the entire vell of the tubing.

\section{Bediogrephie Inspection}

Radiogrophs vere made of the same defective tubing, 0.060 in. ID $x$ $0.080 \mathrm{in}$. OD, used during the ultrasonic developing tests. The defect In the tubing vere $X-$ rayed at both the $0^{\circ}$ and $90^{\circ}$ positions, and tho rediographs vere viewed on on 1lluminator for a visuel examination of the defects.

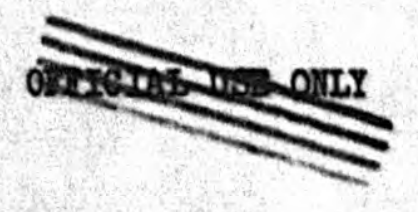


A chert recorder was connected to o densitometer to messure chenges in density of the rediographs of the same defective $0.060-1 \mathrm{n}$. - ID $\times 0.080-1 \mathrm{n}$. - OD tubing used during the ultrasonic tests. With the exception of the $360^{\circ}$ circumferentiol notch defects, the radiogrophs of the tubing vith the defects ot $0^{\circ}$ position coused a much lorger deflection then the radiographs of the some defects ouser obtained in proportion to the width ond depth of the defects. The densitometer ves operated ot $50 \%$ sensitivity (five turins on control knob). Compareble division deflections of the defects ore shown in Table 1.

\section{Eydrostatic Pressure Testing}

A short-time test was made to investigate the effect of the verious depths of notches when internel hydrostatic rupture conditions vere applied. It was found that notches mede on the outside diameter of $10 \%$ to $50 \%$ of the voll thickness did not affect the rupture pressure. Information about the tube end could not be obteined from this test.

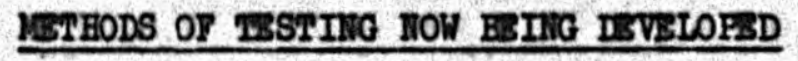

\section{Beta-Ray Gauge (Sr-90 source with 1onization chamber as the detector)}

The primary use for the Beta-Rey Geuge is to messure well thickness. Defects con also be detected with the gauge. A prototype of th1s gauge hes been demonstrated and appears to be very effective.

\section{Cedmium Sulphide Crystel Detector}

Detection of flews in tubing by activating the crystel vith $X$-rays is now in the experimentel stages, and shows considerable promise as a nondestructive test of smoll-diameter tubing.

\section{EQUTPVEMT AID VBTHODS OF ETALDATIOI}

\section{Sperry RePlectoscope Mode1 Ho. 505351}

A standerd model Sperry Ilo. 508351 Reflectoscope was used throughout the tost. The following is a general arrangement of the various individuel circuit employed and their functions:

1. Pulse Trensmitter - Sends out to the emplifier and searching unit a short, high-frequency electric pulse at a low repetition rate.

2. Searching Unit - Receives the electricel pulses from the pulse generator vis the coaxial cable and transforms them, by meens of a plezoelectric quartz cxystel, into mechenicel vibrations and trensmits them into the material being tested. It also is acted upon by the mechanicol vibrations reflected from the meteriel and trensforms these beck into electricel pulses which are delivered to the emplifier vio the cooxiol coble.

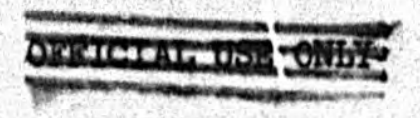




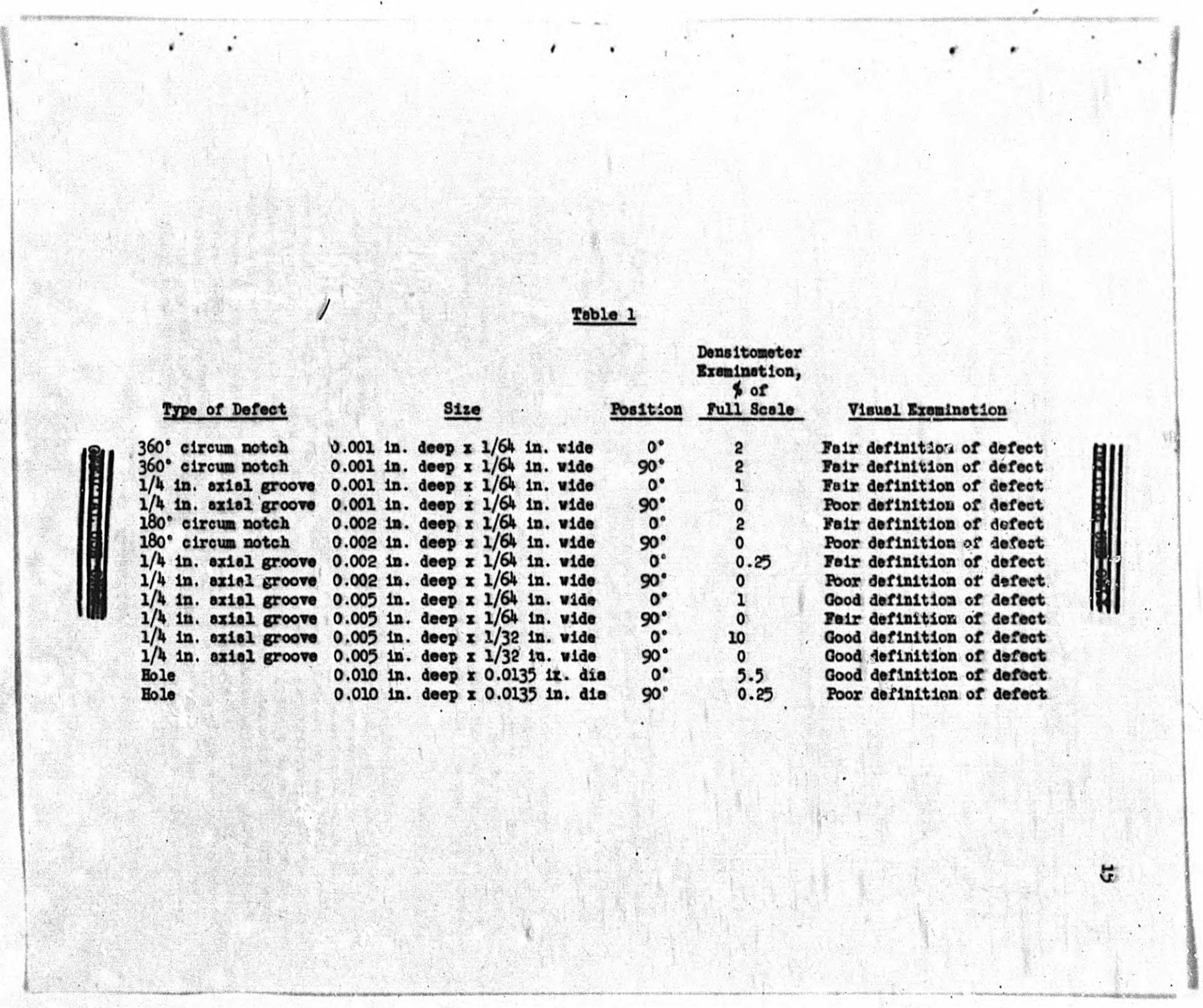


3. Amplifler - Recelves the pulse from the transmitter and the incoming pulses from the sesrching unit, omplifles them, and applies them to the vertical deflection plates of the cothode-ray tube. Tue plotes, in turn, deflect the electron beam of the cothode-roy tube ond couse it to trace out a vertical indicetion of the initiol pulse sent out and of oll reflections received by the searching unit.

4. Sveep clrcuit - Energizes the horizontel deplection plotes of the cothode-ray tube to creote the sweep of the electron beem.

5. Power supply - Furnishes the volteges needed to operote the electronle tubes and the olectron gun of the cathode-ray tube to form the electron bean.

6. Synchronizer - Acts os a tining unit to coordinote the octlons of the other components in order to echleve. the proper timing of the cyele of operotion.

7. Marker c1rcult - Friggered is the synchronizer, energizes the verticel deflection plete of the cathode-ray tube to form the pips which are used to messure the distence units between indications.

Bolder

A holder for testing smoll-Giemeter tubing wes developed and bullt with o geer orrangement for rotatifis the tube steedily and slowly (Figures 1 end 2 ). The steel block holder, 3 In. x 2 in. x 2 in., hes a longltudinal groove to credle the tubing; the geer assembly is ottached ond eligned perpendicular to the groove.

Two pleces of textolite, 2 in. squere, with grooves 0.035 in. deep and $0.040 \mathrm{in}$. redius, were mechined and fitted squerely at each end of the steel block. These pleces repleced a single plece thet extended the frill length of the tubing. This revision ilmited the domping which had previousiy. occurred elong the entire length of the tubing. A definite improvement in sensitirity vas observed due to better sound trensmission.

\section{Seorching Onit}

A standard 1-megacycle Sperry Angle Searching Unit, shown in Figure 4, vas aodifled by cutting $5 / 32$ in. from the face of an angle plexigles wodge to include $1 / 4$ in. plexigles shoe vith groove $(0.035$ in. to 0.040 in. rodius) along the diameter. The plexiglos shoe has o bevel edge opproximately $3 / 4 \mathrm{in}$. long on the outer surface opposite the side of the groove. Th1s bevel edge linits the rotetional or lentation of the shoe vith respect to the holder by coinciding with o bakelite tip protruding through the angle plexigles vedge that sets in the housing. Coupled with a light oll the ongle plexigles vedge and the ongle bokelite vedge ore set into a holder ond held by two screws shown in Figure 3. The plexigles shoe cen be mede to rotete slightly elther clockn1se or counter-clockw1se on the surfece plexigles vedge. Th1s permits orlentetion of the tubing with respect to the quartz crjstel for maximum transalssion of sonic energy. If the plexiglas shoe is roteted to a point 
which exceeds the breaking point of the oll seal, poor transmission results. Elowever, breaking the oll seal by this method does permit interchanging plexigles shoes thet heve been ground to different pipe curvatures. The depth of the grooves in both the plexigles shoe and the textolite pleces held fost on the holder is slightly less then the dismeter of the tubing, thus permitting a firm direct contect to the tubing being tested, ond focilitating better sound transmission.

\section{Coupling 011}

SAE Fo. 20 lubricont oll was the snly coupling used with the tublng during the test procedures. The results vere sat1sfectory, so no other types of coupling were tried inasmuch as the surfeces of the vorking parts were smooth and in almost direct contact with each other. A lighter o11 coupling should olso glve sat1sfoctory results.

\section{Crystals and Frecuency}

Verlous stendard ongle searching units and different designs of plexiglas shoes were tried during test procedures. The best results were obtalned with - l-megecycle, l-1n. quertz-crystel angle searching unit. Higher frequency crystels, $21 / 4$ megacycles and 5 wegecycles, were olso tried, but were unsuccessful due to high ottenuation of the sonic energy.

Barium t1tenate $\left(\mathrm{BaTlO}_{3}\right)$, e more sensitive tronsducer which is now being used in uitrasonic flav detection, has been used successfully in surfoce testing thin sheet mater101. Because of the sensitivity of the $\mathrm{BaTIO}_{3}$, excessive nolse resulted when It was used to test smell-diemeter tubling.

\section{Cemera}

Photographs and reflectograms vere taken with a special adapter camero which was mede by a member of the Nondestructive Test Group.

\section{Art1f10al Defects}

During the development, reflectograms and tests were mede on various 8120 notches, smell holes, and grooves. All clrcumferent1el notches vere cut on the tubing with a grinding disc. The tubing was supported and rotated in a lathe. Axiol grooves vere made vith special tool on a milling machine.

\section{Ultrasonic Path through Vell of Tubing}

By rotating the tubing with the angle searching unit placed at one end, directing the angle boan toward the opposite edge, and moving the trensducer longltudine $12 \mathrm{y} 1 / 2$ in. or 1088 , the entire length of the tube vas inspected. 


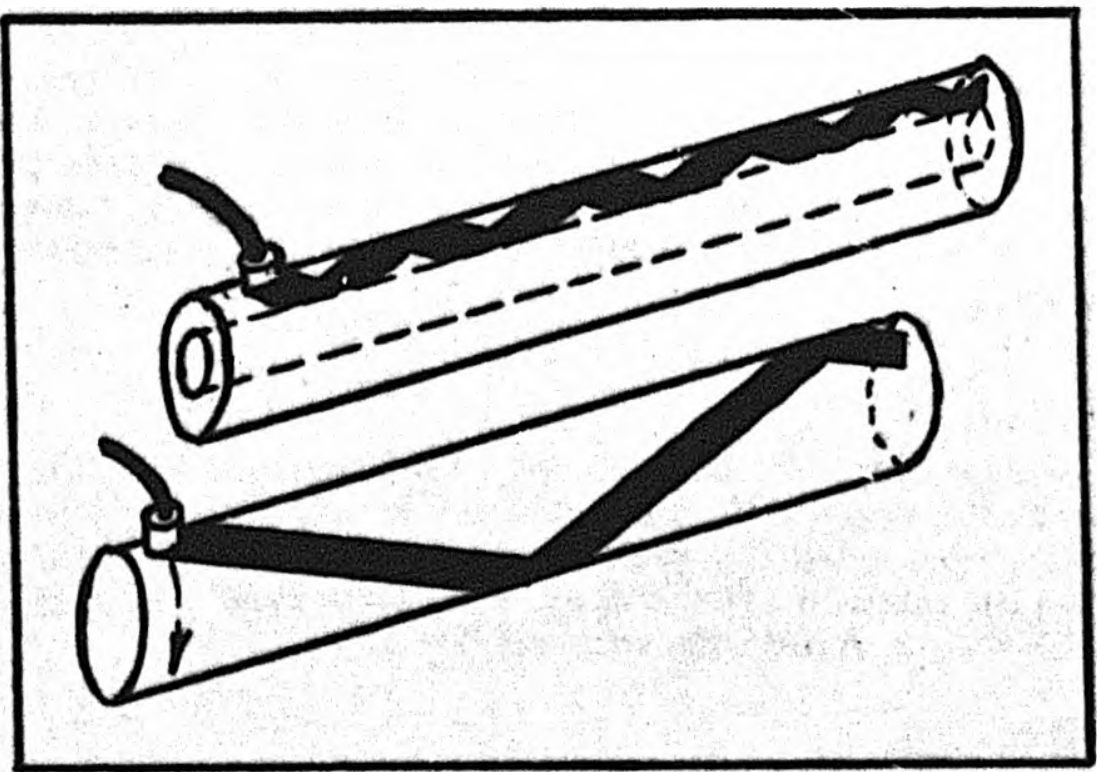

8ketch showing the Path of the sound Boen when Testing Tubing and Bar stook

\section{Cellbrated Eotch}

The size of the defects found in any given number of tubes of the seme type wes meesured ond compered vith a otenderd cellbreted notch wede on 8 inllar type tubing. The cellbreted notch, which in this cese ves 0.001 in., ves mede epproximetely $4 \mathrm{in}$. to $8 \mathrm{in}$. from one end of o stenderd plece of tubing. The cellbrated notch could not be pleced too close to one ond of the tube os the end reflection Interfered vith the Interpretetion of the cellbretion. When a defect lay neer or at the end of the tubing, the pleture vived on the reflectoscope scroen ohoved the indication ot o tengent to or on top of the beck reflection. To seperate the indicetion from the beck replection, pressure demping wes opplied ot the end of the tubing.

\section{Sensitivity}

Meximum sensitivity edjustment of the reflectoscope wes not roguired to obtain Good results for interpretetion of rmell size defects.

The sonsitivity for eech reflectogren taken vas inereased just enough to give a verticel beck reflection Indieetion equal to the holght of the sereen. By this mothod, the defect Indicetivas in the reflectogrems vere shown compereble to the beck reflection. A lerger Indieation of the defect wes mede vialble on the sereen by Inereesing the sensitivity, but the Ineresse in defect Indicetion vas directiy proportionel to the increese in nolses and beck refloction. 


\section{IITYSRPRETATION OF REIPIECTOGRAVIS}

In 011 but one of the reflectograms taken, 8 l-megacjcle angle searching unit was pleced on the tube $16 \mathrm{in}$. From the end with the lnown defect. The average length of the tubes was 24 inches.

The reflectograms included in this report show the defects betweed the two largest indications. The initial pulse is the large inalcotion at the left, and the bock reflection is the lorge indication at the right.

With a reject setting of zero on the reflectoscope throughout the test procedures, reflectograms were made and recorded as follows:

$\frac{\text { Figure } 5}{\text { - Defect: None }}$ Indication left to right - initiol pulse and back reflection. Wo defects.

F1gure 6 - Defect: P1le marking, approximately 0.005 in. deep, $40^{\circ}$ circumferentially, 2 in. from one end of tube.

Interpretation: Midale Indleation shows defect is $33 \%$ of back reflection.

F1gure I - Defect: Notch 0.002 in. deep, epproximately $1 / 32$ in. vide, $180^{\circ}$ circumferentially, 2 in. from end of tube.

Interpretetion: Second Indication from left shows defect is $17 \%$ of beck reflection.

F1gure 8 - Defect: Wotch 0.002 in. deep, epproximately $1 / 32$ in. v1de, $180^{\circ}$ circumferentially, 3 in. from one end of tube.

Interpretation: Second Indication from left shows defect is $17 \%$ of beck reflection.

Plgure 9 - Defects: Two circumferentibl notches vere mede 3 in. and 4 in. from end of tube, respect1vely, $0.002 \mathrm{in}$. and $0.001 \mathrm{in}$. deep, $180^{\circ}$ and $360^{\circ}, 1 / 32$ 1n. v1de.

Interpretation: Second and third Inalcotions show defects side by 81de. By orientation of the tubing, indication of elther defect can be mede to chenge 1ts magnitude.

Flgure 10 - Defect: Motch 0.001 in. deep, $45^{\circ}$ e1rcumferential1y, opproximately $1 / 64$ in. v1de, 2 1n. from end. Anglo searching unit was pleced 7 in. frot end of tho tube and closer to the defect to obtain better olerity.

Interpretation: 8ocond indication from left shows defect is approzimately $8 \%$ of back reflection. 
Figure 11 - Defect: Axial groove opproximately 0.005 in. deep, 1/4 in. long, $1 / 32$ in. vide, ond 2 in. from the opposite end of the tube.

Interpretat1on: Second lergest indication frosi the left, $13 / 8$ in. peak to peak, represents the defect. Becouse of the loss of back reflection, sensitivity was increesed in order to show the defect indicetion more distinctly.

Flgure 12 - Defect: Seme notch as referred to in Figure 10, but w1th increesed sensitivity. Angle seerching unit 18 now 16 in. Insteed of $7 \mathrm{in}$. From end of tubing.

Interpretation: Indications, Including no1se, ore ell increased in magnitude. They heve approximately the same proportionel relotionship to each other.

F1gure 13 - Defect: One hole, $0.0135 \mathrm{in}$. In diameter, wede through $0.010-1 \mathrm{n}$. well, with a llo. 80 drill, 4 In. From ond of tubing.

Interpretetion: Second indication from left shows defect oppror1mately 30 of beck reflection.

Figure 14 - Some tubing os reforred to in Figure 13 vith 1ncressed sensitivity. Defect: Ho. 80 drilled hole

Interprstation: Indicetions, including nolse, all increased in megnitude. They heve epproximately the some proportionel relotionship to each other.

Figure 15 - Defect: Axiel Eroove epproximetely 0.005 1n. deep, 1/4 in. 10ng, 0.006 in. vide, 4 in. From end of tube.

Interpretation: Second Indicetion from left shovs defect approximately $15 \%$ of beck reflection

Flgure 16 - Same tub1ng as referred to in F1gure 15 with Incressed sensitivity. Defect: Axiol Eroove

Interpretation: Indications, Including noise, oll increased in negnitude. They heve approximately the seme proportional relot1onship to each other.

P1gure 17 - Defect: Solid stainless steel rod, 0.080 in. In dieneter, no defects.

Interpretetion: Better trensal ssion of sound. From left to right ore Initiel pulse, first and second orders of beck reflections.

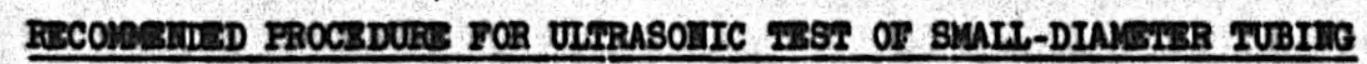

1. Connect the Sperry OItresonic Beflectoscope through the sole trensformer to the power source. Comnect the ground post to a sulteble ground. Turn the pover on and ollow o minute or two for vermup. 
2. Neamuile, ottach the l-megacycle, 1-in. ongle searching unit and cable, end turn the frequency suitch on the reflectoscope to 1 megreycle setting.

3. Attech and align the tubing to be tested in the groove of the holder perpendicular to the gear assembly.

4. Apply SAS Ho. 20 couplant o1l only on the end of the tubing at which the searching unit is to be pleced. Bxcessive douping occurs if the entire length of the tube is cooted with oll.

5. Place the 1-megacycle 1-1n. angle searching unit on the coupling surface and wipe the surfoce to obtein good contact.

6. Proceed to odjust the instrument for mezimum clarity in accordence with the $0.001-$ in. colibrated notch.

7. Adjust the sweep length unt1l only one bock reflection is visible on the screen.

8. The replectoscope is now resdy to begin testing, and the indications obteined on the vieving sereen can be interpreted.

9. Nove the searching unit closer to the defect to increase the mognitude of the indicetion.

10. Place the eingertips on the tubing to damp the sound beem in that port1cular area. 


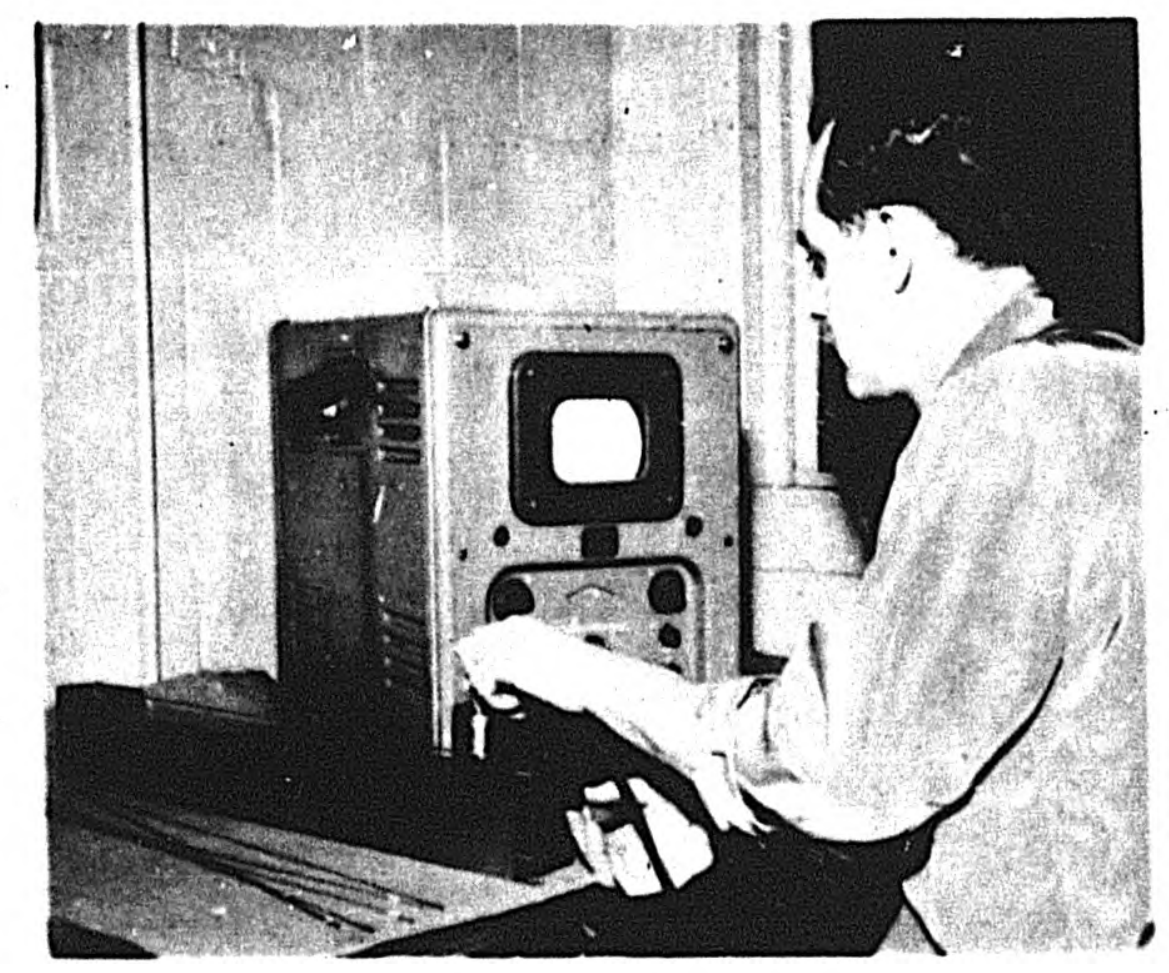

FIQ. 1 TESTINO SETUP

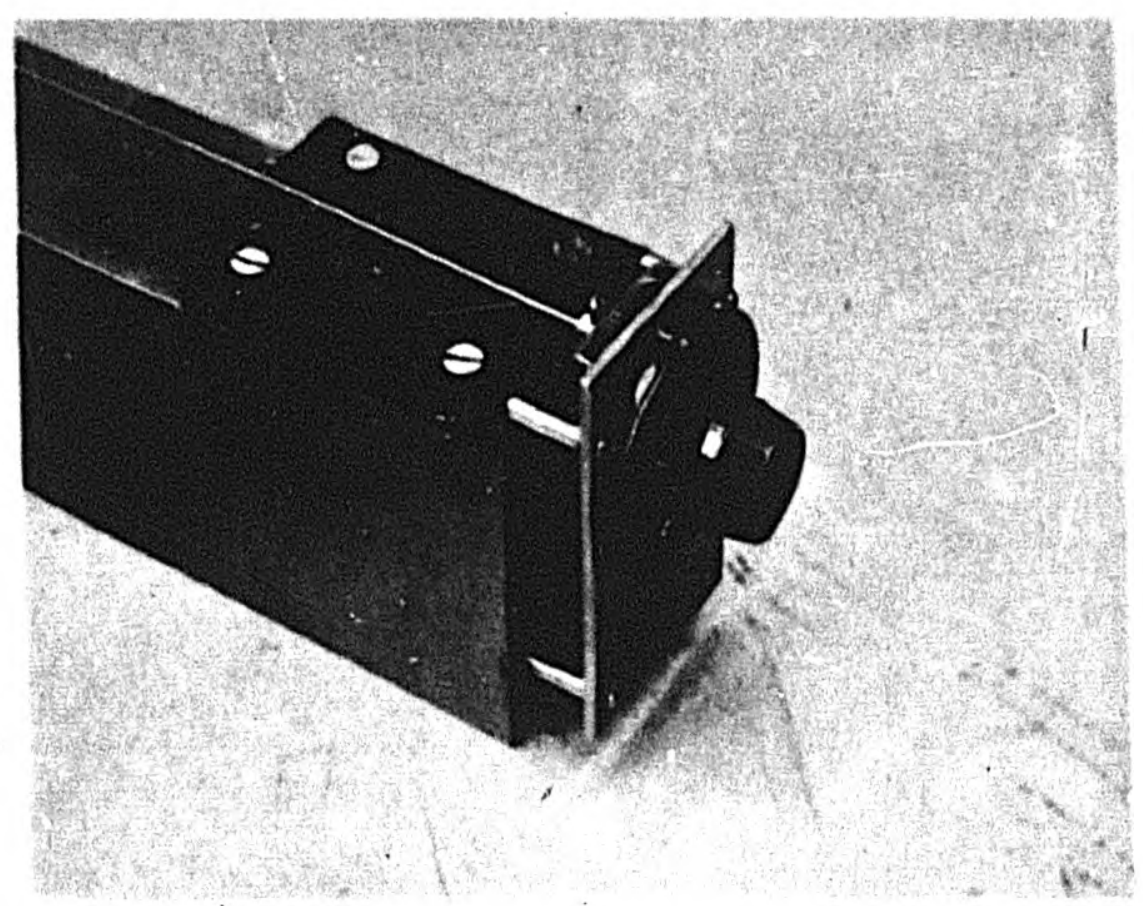

II0. 2 HOLDER AND OFAR ARRANOEISNT 


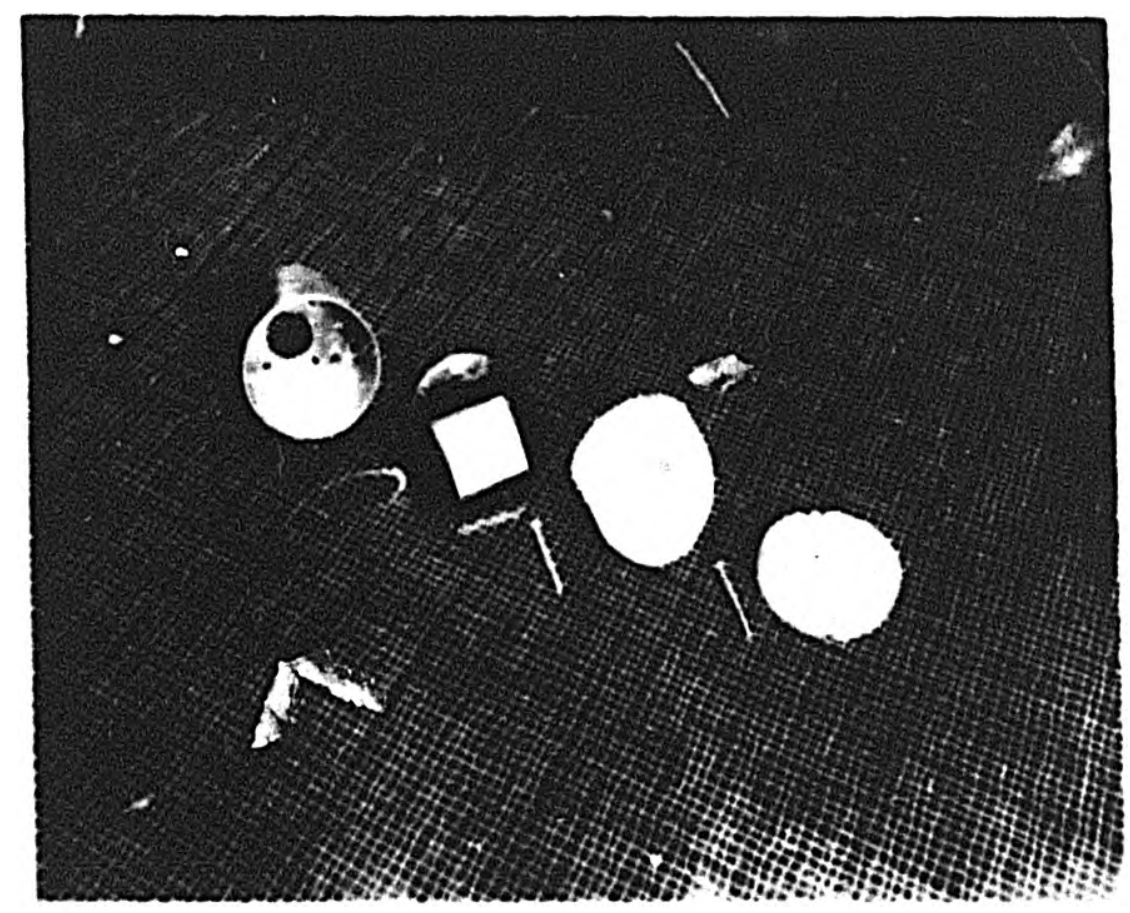

FIG. 3 LAJAR COMPGIETS OP I" ANGLE GRARGHINO UAIT. RT. TO IETT 1. HOUSING 2. CRYSTAL ATTACHES TO BAKELTTE BACKINO. 3. PLBKLOLAS IEDOS. 4. PLEXTLLAS SHOF

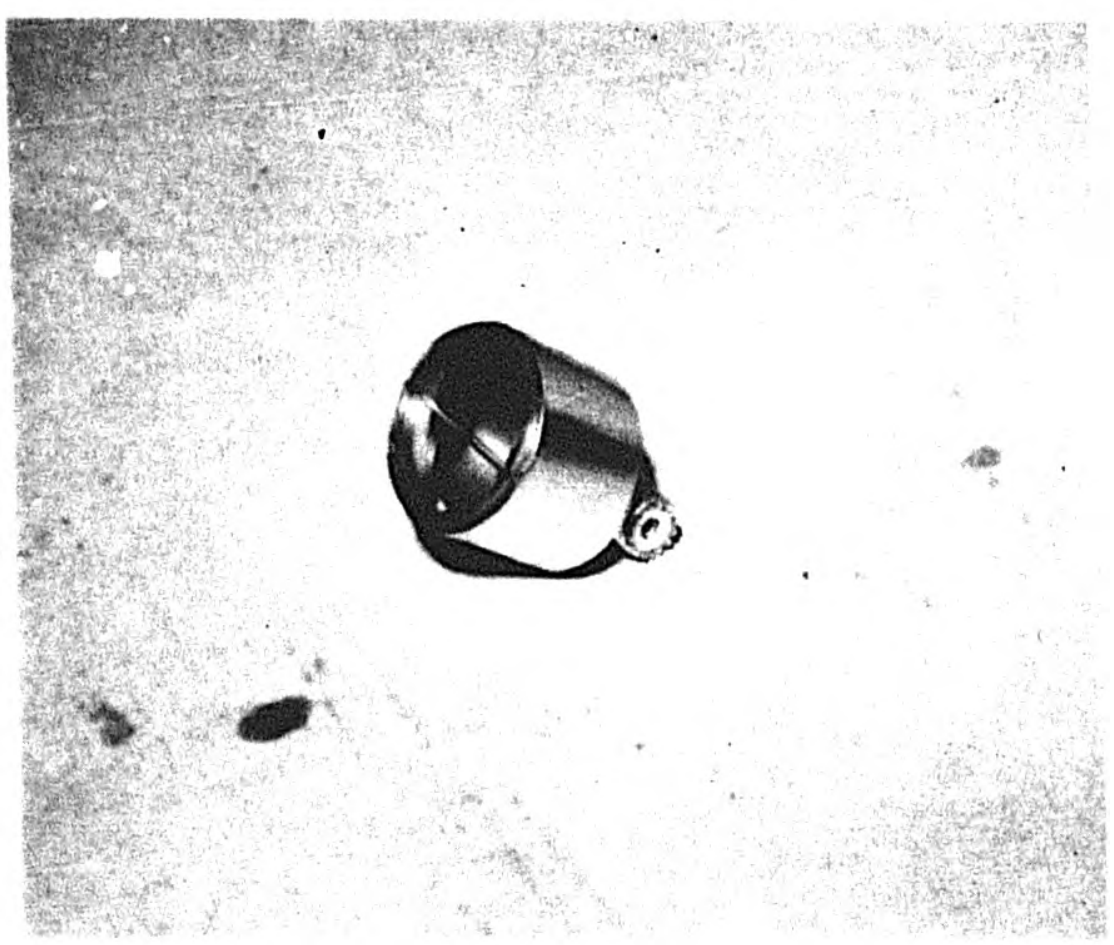




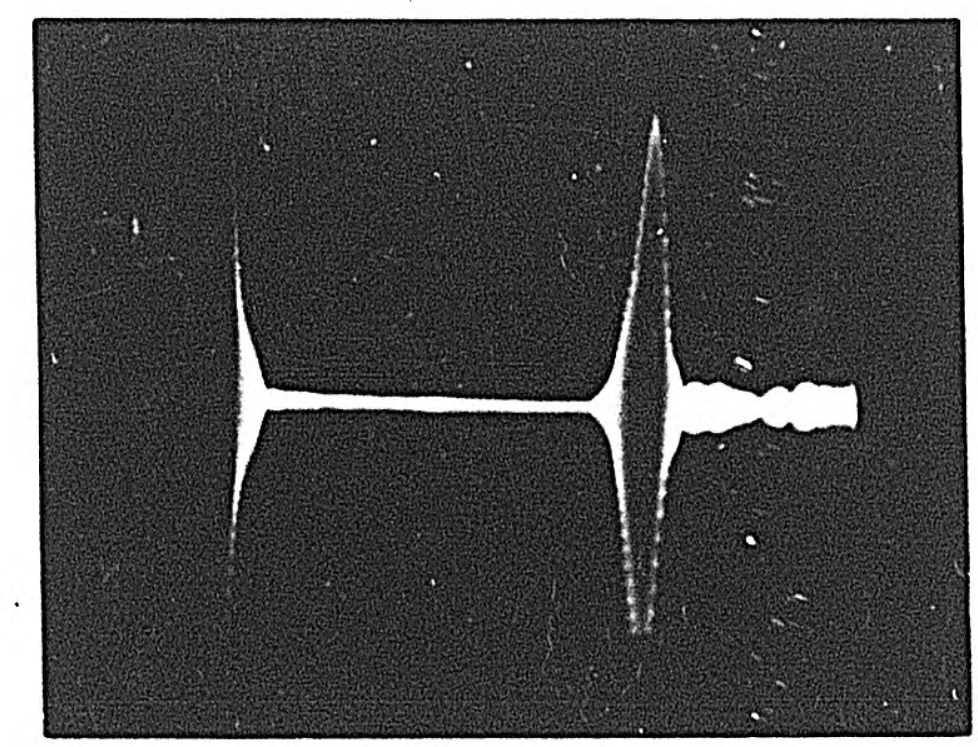

FIG. 5 DIITIAI PULSE - NO DETECTS BACK RELECTIOA

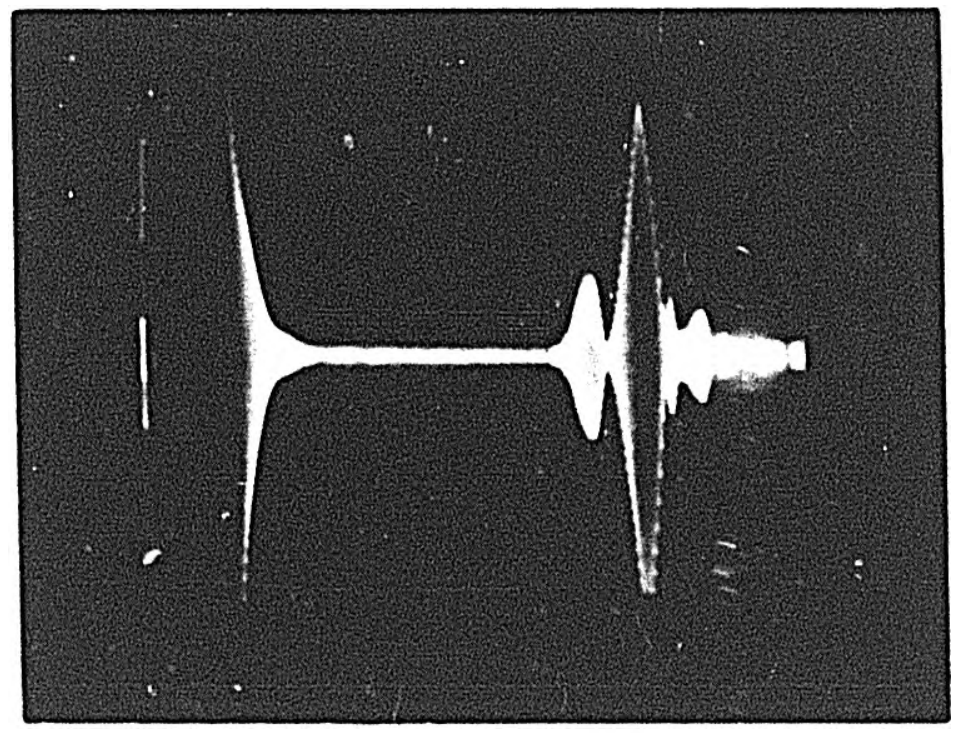

FIO. 6 FILS NOTCH DEFECT, $40^{\circ}$ CIRCUMFERBTIAL, .005" DESP 


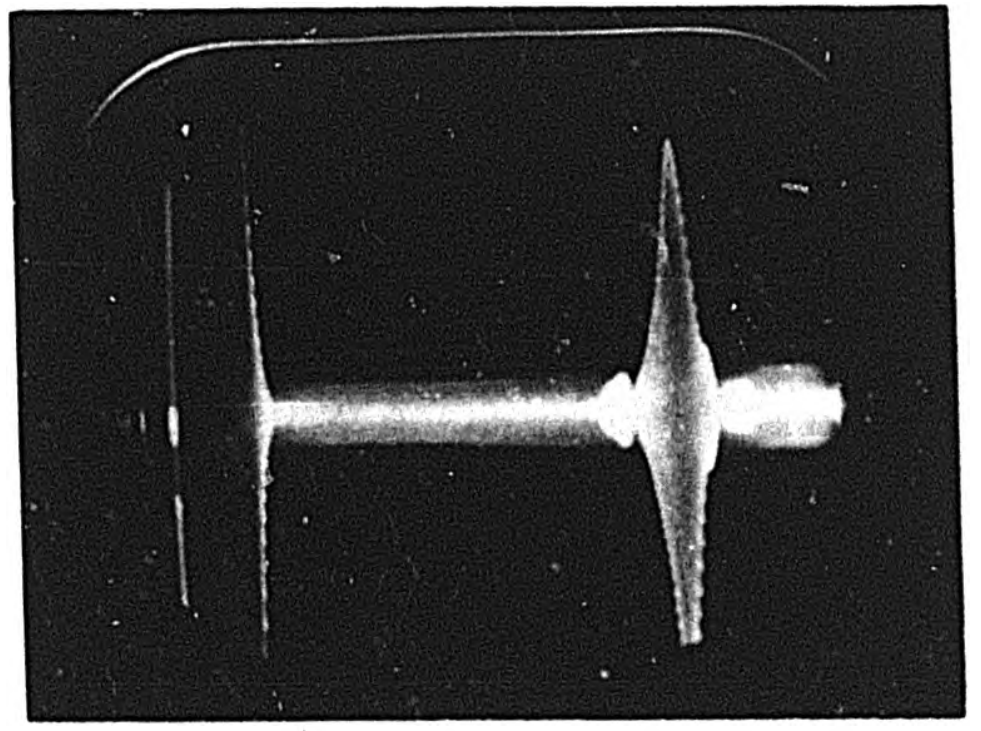

FIG. 7 NOTCH DEFBCT, $180^{\circ}$ CIRCUMFERENTLL, $.002^{\prime \prime}$ DESP, 2" FROU END OF TUBE

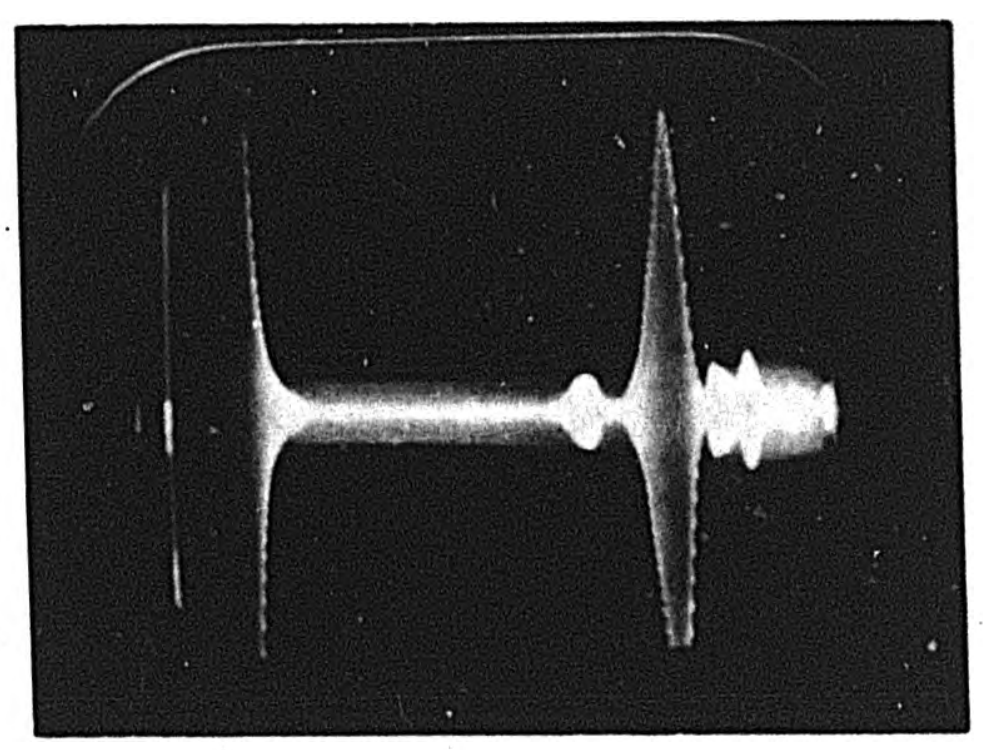

FIO. 8 NOTCH DEFECT, $180^{\circ}$ CIRCULFERETIAL, $.002^{\prime \prime}$ DRBP, 3" FROU END OF TUBE 


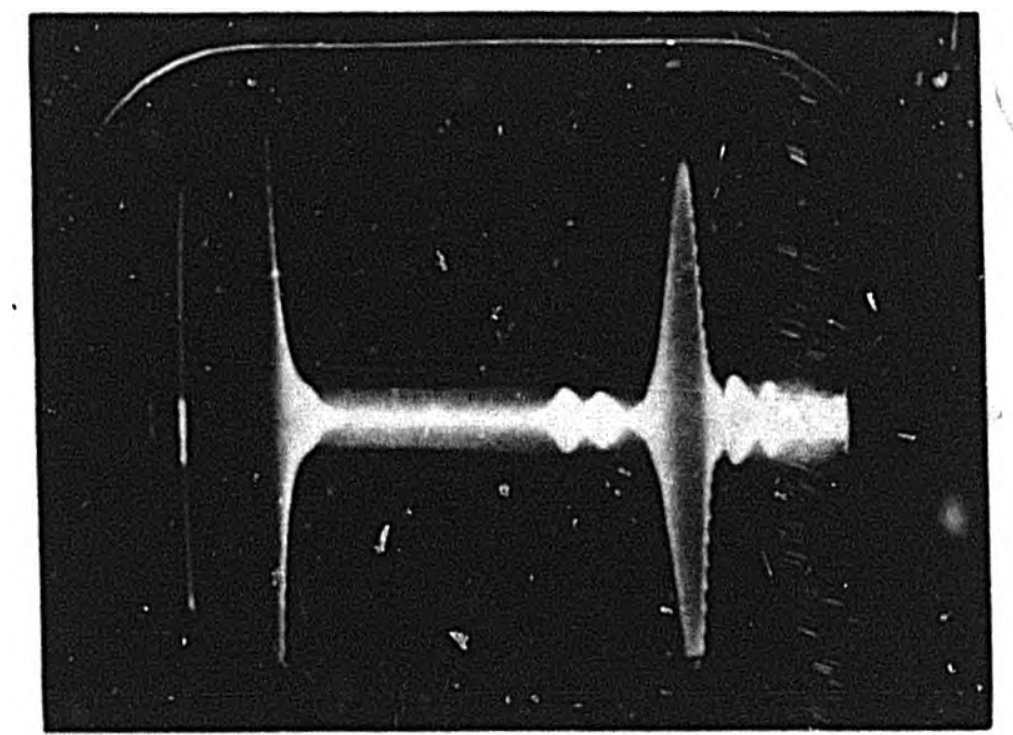

FIG. 9 DOUBLE NOTCH DEPBCT, .002n \& .001" DEEP, 3" \& 4" RESPECTIVEIY FROU END OP TUBB

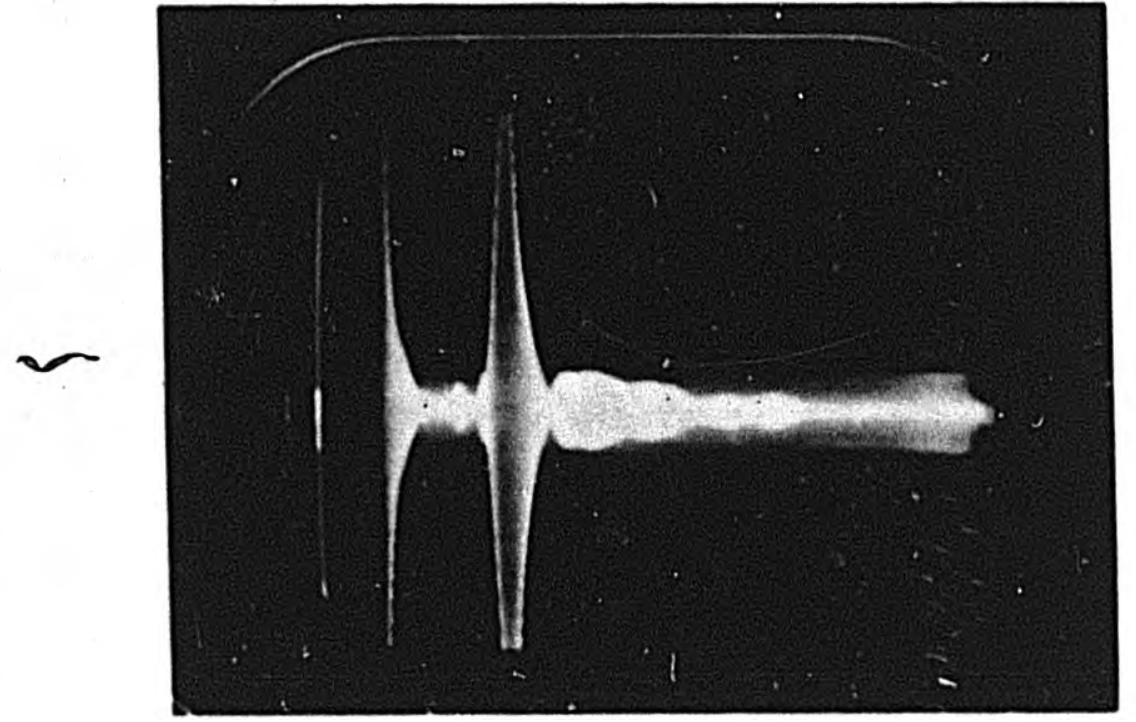

FIO. 10 NOTCH DEFECT, $45^{\circ}$ CIRCURERENTIL, $.001 "$ DEEP, NNOLE SEARCHINO UNIT 7" FROI EDD OP TUBE 


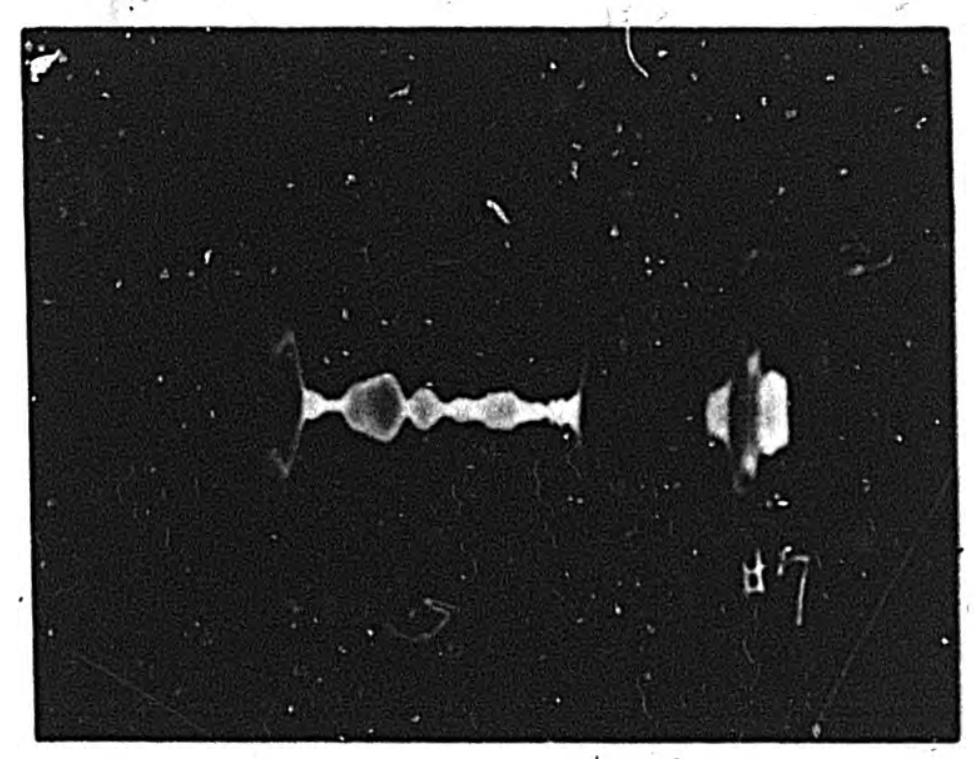

FIO. 11 NTAL GROOVE DEFECT, 1/4" LONG, 1/32" WIDE, .005" DEEP, 2" FROU END OF TUBE.

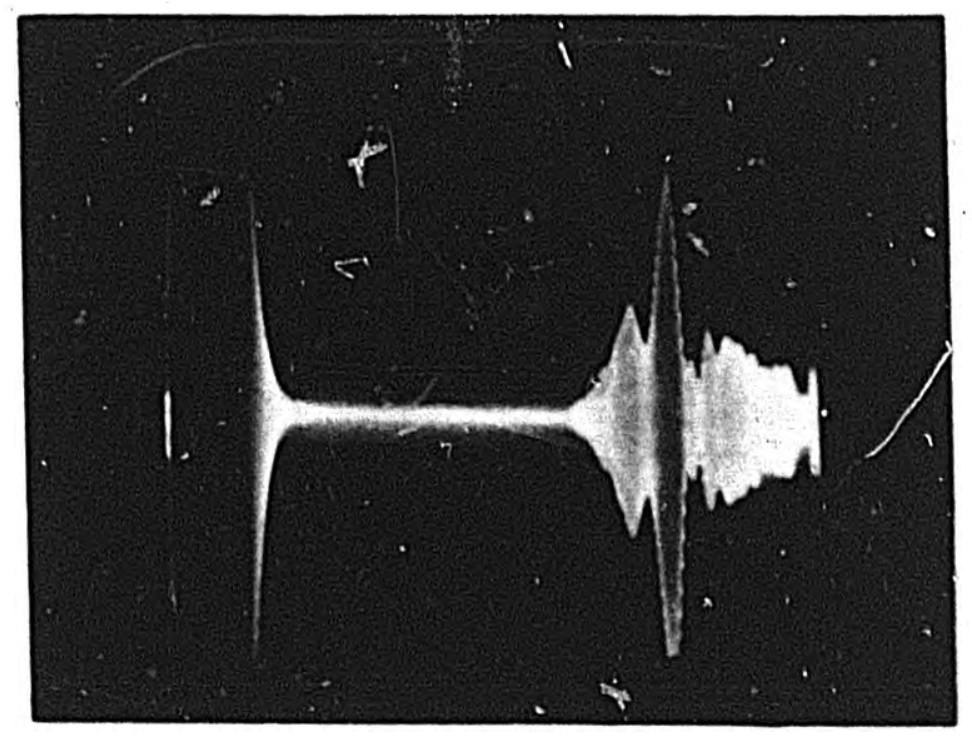

FIG. 12 SNM NOTCH DEFECT IS SHOW IN FIG. 10, DNGREASED SENSTIT IVITY, ANORE SEARCHINO UNIT 16" FROM END OF TUBE 


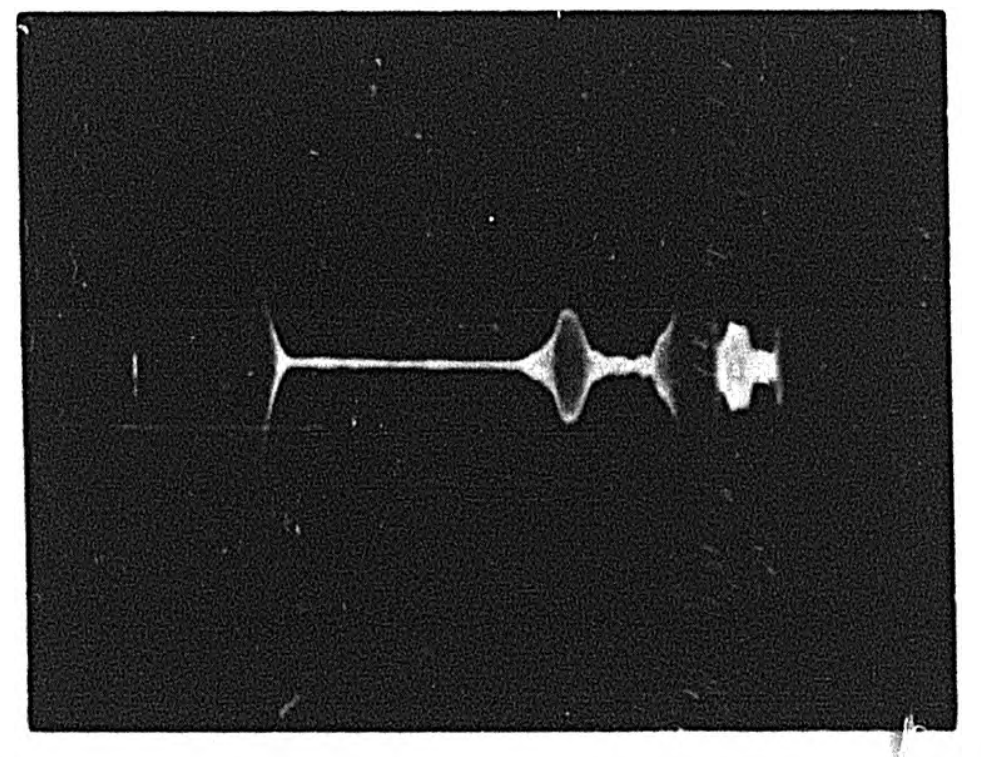

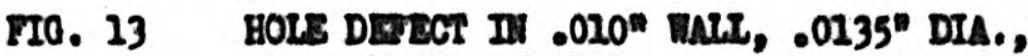
$4^{\prime \prime}$ FROU EDD OP TUBE

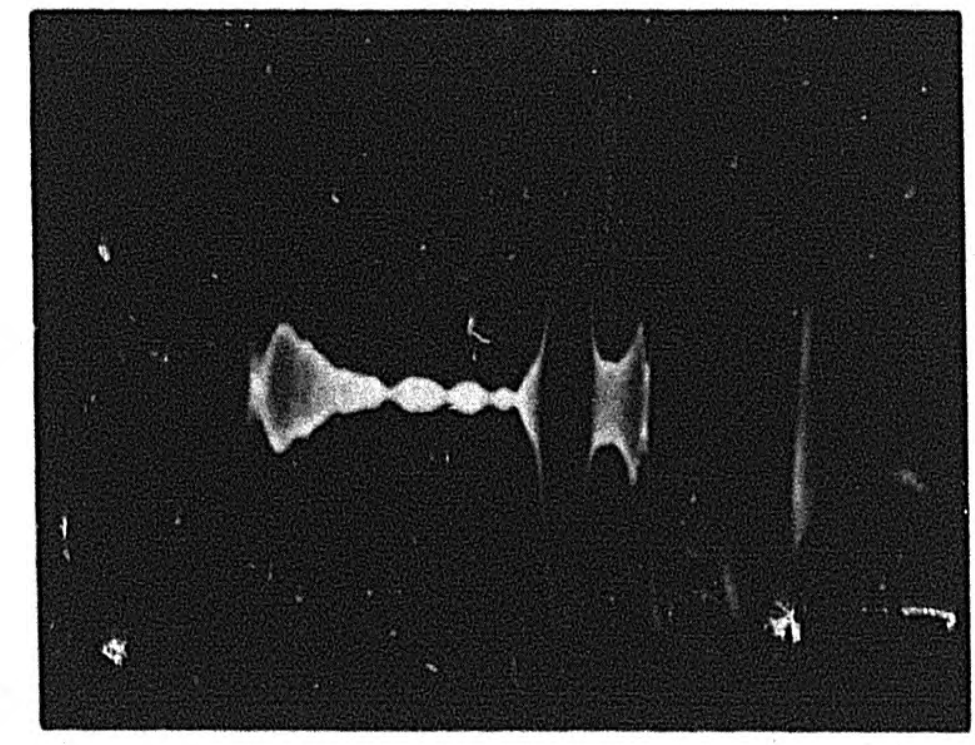

FIO. 4 SATS DEFECT AS SHOW IN FIO.' 13, INCREASED SENSITIVITY 


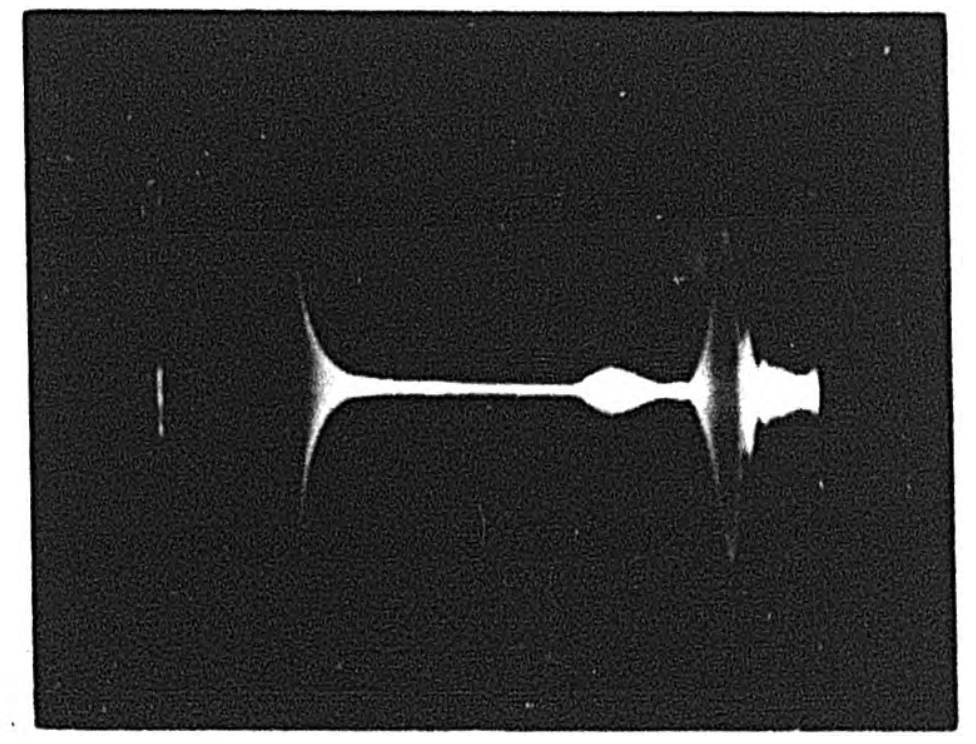

FIO. 15 AXTAI OROOVB DEFECT, 1/4" LOASO, .006" WIDE, .005" DESP, 4" FROM ERD OF TUBMIO

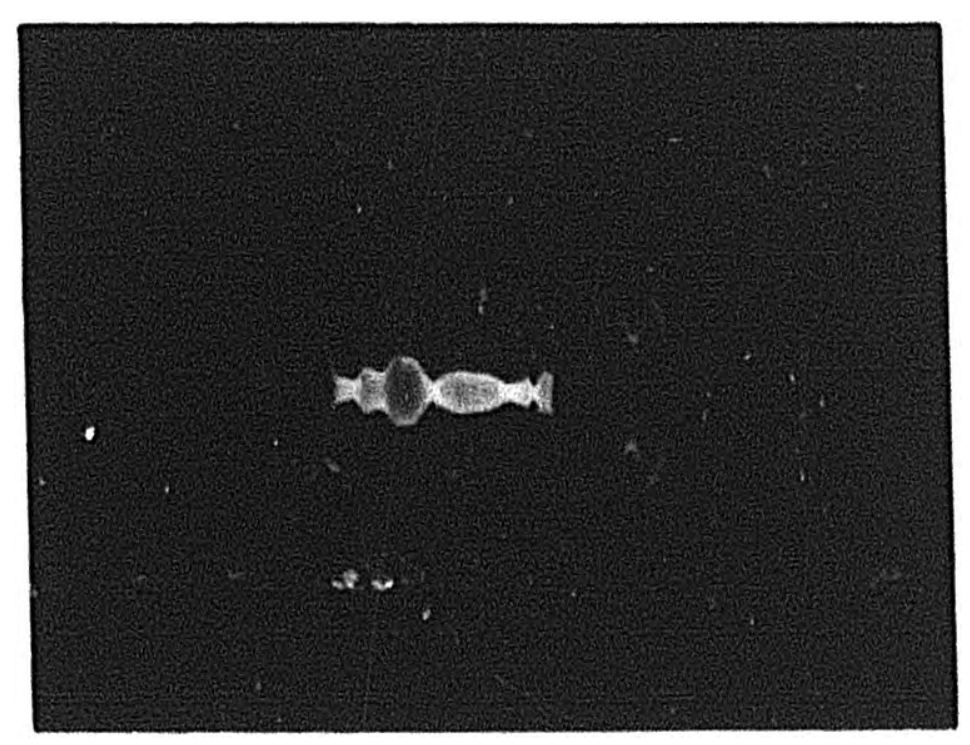

PIO. 16 SAMB DEFECT AS SHON IN FIO. 15, DICREASED SESSTTIVITT 


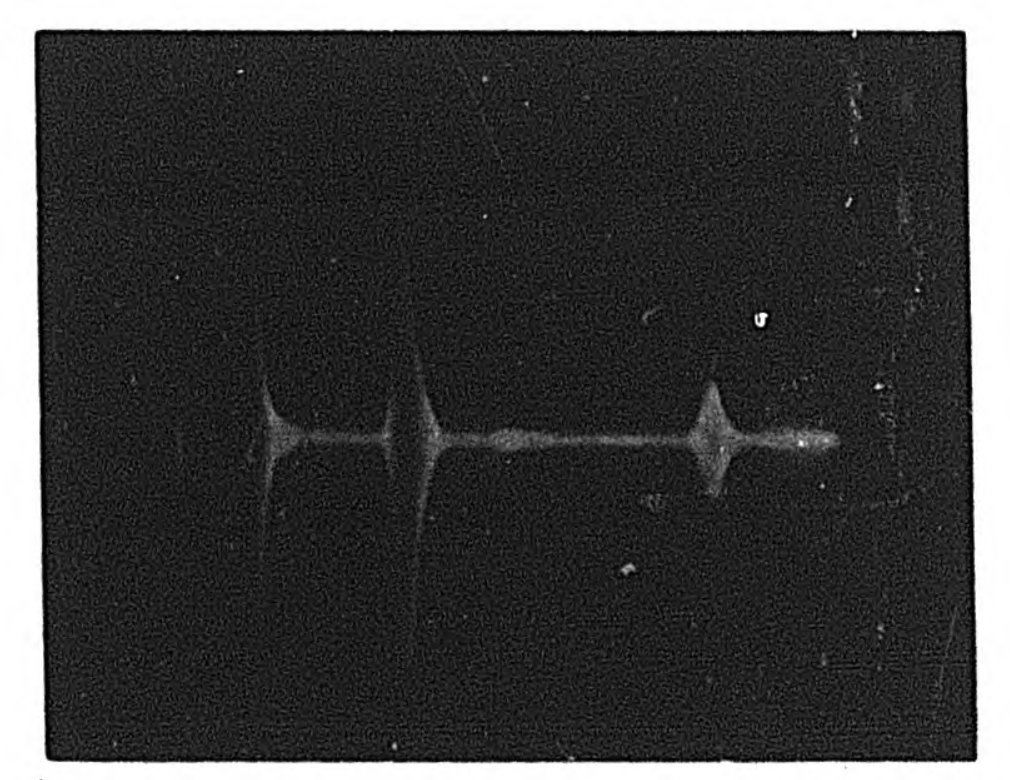

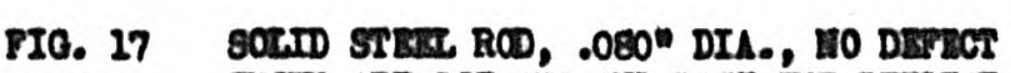

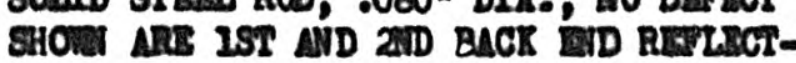

Iars.

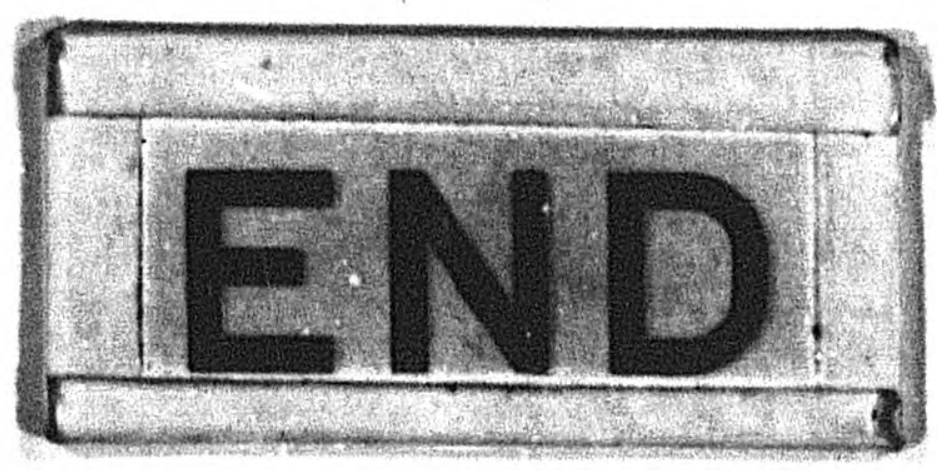

